\title{
KEBUNTUAN PEMAHAMAN TERHADAP POLEMIK WACANA ISLAM NUSANTARA: KAJIAN DARI PERSPEKTIF MAKNA PRAGMATIK
}

TAUFIK NURHADI

Received: 22 Juni 2020; Accepted: 1 Juni 2020; Published: 7 Juli 2020

Ed. 2020; 3 (2): 143 - 154

\begin{abstract}
This study is aimed at describing of the impasse understanding of the polemic of the Nusantara Islamic discourse. The data were in the form of Indonesian language used in the polemic of the pros and cons of the Nusantara Islam issue, which is published on social media, Youtube. Data collection uses the method of listening with tapping, SBLC, download, and note techniques. The data analysis method used is Constant Comparative Analysis. The results of the analysis showed that there was a deadlock in understanding the issues of the Nusantara Islamic discourse regarding 4 things, namely symbolic identity, rejection in terms of terms, classic rivalry between tribes, and culture as the core problem. The deadlock of understanding was triggered by long competition between the two circles of Muhammadiyah and Nahdatul Ulama in viewing worship practices from different perspectives.
\end{abstract}

Keywords: deadlock, Nusantara Islam, polemic discourse, pragmatic meaning.

\section{PENDAHULUAN}

Perbedaan pendapat di kalangan umat Islam tentang masalah amalan demikian dinamis dan terbuka, khususnya kehadiran wacana Islam Nusantara yang menimbulkan pro dan kontra di kalangan umat Islam. Wacana tersebut sebenarnya sudah dikembangkan setidaknya sejak abad ke-16, tetapi gaungnya menjadi menguat setelah disosialisasikan dalam Muktamar Nahdatul Ulama ke-33 pada tanggal 3 Juni 2015 di Jakarta.

Sebenarnya polemik Islam Nusantara merupakan bagian dari polemik-polemik lain yang terakumulasi dari persaingan antara dua organisasi Islam terbesar di Indonesia, yakni Nahdatul Ulama dan Muhammadiyah. Ini merupakan fakta yang tidak bisa dipungkiri karena sejarah menunjukkan bahwa permasalahan yang diangkat oleh kedua organisasi ini adalah masalah klasik, yaitu khilafiyah, yang memiliki pengertian 'perbedaan sikap, pandangan, atau pendapat dalam hal perkara amal ibadah.'

Urgensi polemik wacana Islam Nusantara adalah kehadirannya telah terpublikasi di media sosial yang bisa diakses oleh siapapun dan sarat dengan kepentingan. Indikasi lain adalah terdapat kecenderungan bahwa kehadiran polemik wacana Islam Nusantara tidak lebih dari pernyataan-pernyataan spekulatif ketimbang penyampaian fakta empiris. Bahan polemik sudah tidak menjadi diskusi yang dikemas dengan media bahasa yang elegan dan santun, melainkan menjadi sasaran pernyataan- 
pernyataan yang berisi penilaian, kritikan yang bersifat menghakimi, pengindoktrinisasi, dan bahkan tidak jarang terlontar kecaman dan hujatan (LIH. BASALAMAH, 2015; ALI, 2018).

Dari segala bentuk polemik tersebut, masyarakat Islam di Indonesia menjadi terakumulasi dalam himpunan dua kelompok pro dan kontra dengan menempatkan wacana Islam Nusantara sebagai sengketa. Anggota organisasi Islam dalamsatu atap pun bisa terbelah. Misalnya kasus pro kontra Islam Nusantara terjadi di tubuh organisasi fatwa MUI (Majelis Ulama Indonesia), pada satu sisi MU Sumatra Barat secara tegas menolak istilah Islam Nusantara, yang mendapat respon keras dari MUI Pusat yang menganggap penolakan itu menyalahi khittah dan jati diri MUI itu sendiri. Lebih lanjut MUI Pusat menyatakan bahwa MUI seharusnya menjadi garda depan penyemangat ukhuwah (persaudaraan), tasamub (toleransi), dan tawazun (moderasi) dalam menyikapi berbagai persoalan khususnya yang berkaitan dengan masalah umat Islam (Republika.co.id, 20 Juli 2018). Peringatan MUI Pusat tidak menyurutkan sikap MUI Sumatra Barat, melalui ketuanya, Buya Gusrizal Gazahar, menuangkan penolakannya melalui akun media sosialnya berupa artikel yang berjudul "Amanah Kami Tunaikan," yang intinya menyatakan bahwa istilah Islam Nusantara yang digagas oleh sebagian umat Islam, yang disebarkan dengan kekuasaan dan mengarah ke berbagai institusi, justru jauh dari taswiyyatul manhaj, yang telah mengabaikan bagian umat Islam lain yang belum tentu bisa menerima konsep yang diusung tersebut (GUSRIZAL, 26 Juli 2018).

Berdasarkan fakta tersebut, penulis beranggapan bahwa isu wacana Islam Nusantara cukup urgen untuk diangkat dalam penelitian. Urgensinya terletak pada kesimpangsiuran pemahaman terhadap wacana Islam Nusantara, lebih-lebih isu tersebut terekspos dan terpublikasi di media sosial yang sarat dengan hoaks dan kepentingan individu maupun golongan. Dengan demikian, penelitian ini akan difokuskan pada terjadinya kebuntuan pemahaman terhadap konsep Islam Nusantara yang berakibat munculnya dua kubu pro dan kontra.

Menimbang hal tersebut di atas, diajukan rumusan masalah sebagai berikut:

(1) Apakah terdapat kebuntuhan dalam memahami konsep Islam Nusantara?

(2) Faktor apakah yang mendasari timbulnya kebuntuan dalam memahami konsep Islam Nusantara?

\section{Dasar Teoritis}

Penelitian ini membahas tentang kebuntuhan pemahaman terhadap konsepsi Islam Nusantara berdasarkan pada dua perspektif dari kedua pihak yang pro dan kontra terhadap Islam Nusantara. Ada istilah kunci yang perlu dijelaskan terlebih dahulu dalam studi ini, yakni kebuntuhan pemahaman. Istilah tersebut berarti 'ketidakberhasilan memberi pengertian terhadap sesuatu.' Kata sesuatu yang dimaksud dalam studi ini adalah "media verbal" atau "bahasa" yang digunakan baik oleh kubu yang pro maupun kontra dalam berpolemik isu wacana Islam Nusantara.

Karena studi ini menyangkut makna, diperlukan dasar kajian yang memadai, yang dalam hal ini digunakan teori makna tripartit. Artinya, teori ini memiliki tiga tataran makna, yakni makna referensial, makna sosiologis, dan makna psikologis. Ketiga tataran makna tersebut merujuk pada pemahaman makna dalam kaitannya dengan dinia fakta (makna referensial), dalam pikiran penutur (makna psikologis), dan penggunaan tuturan atau fungsi sosial (makna sosial) (CUMming, 2007; MAY, 2009; Cummings, 2014; NURHADI, 2014). 
Konteks tutur juga dipertimbangkan untuk memahami studi makna berdasarkan tiga tataran makna tersebut, yang meliputi grammatical context, social context, situational context, dan cultural context (BUBLITZ dkk., 2011; LOCASTRO, 2012; Nurhadi, 2014; PENNISI dan FALZONE, 2020).

Dalam kaitannya dengan konteks, akar permasalahan konflik perlu dijelaskan sebagai dasar untuk memahami permasalahan yang dikaji dalam studi ini. Akar permasalahan yang dimaksud adalah kehadiran wacana Islam Nusantara. Dalam beberapa sumber, Islam Nusantara merupakan perwujudan empiris Islam yang dikembangkan di Indonesia, yang setidaknya dimulai pada abad ke-16. Gagasan ini muncul sebagai akumulasi dari hasil interaksi sosial, indigenisasi, kontektualisasi, intepretasi, dan vernakulasi terhadap nilai dan ajaran Islam yang bersifat universal, sebagai realitas sosiokultural Indonesia (Wikipedia, 2020). Wacana ini digagas oleh para ulama Islam di bawah naungan organisasi Islam terbesar di Indonesia, yaitu Nahdatul Ulama. Gagasan Islam Nusantara tampaknya direspon negatif oleh sekelompok orang Islam yang kebetulan di bawah naungan Muhammadiyah. Mereka tidak setuju terhadap gagasan tersebut. Pada akhirnya terjadilah perselisihan yang mengarah ke khilafiayah. Apabilah ditelusuri akar permasalahan mengapa bisa terjadi perselisihan paham, saya pikir itu tidak terlepas dari perbedaan prinsip dalam menyikapi hukumhukum Islam. Ada satu dalil yang dikemukakan ulama Muhammadiyah yang menjadikan sumber konflik adalah "Kullu bid'atin dholalah, wa kullu dhollalahtin finnaar." Dalil inilah yang dijadikan oleh ulama Muhammadiyah untuk menghakimi amalan-amalan ulama Nahdatul Ulama dengan istilah "sesat." Dengan dasar konteks ini lah diharapkan permasalahan yang menjadi studi kajian dalam artikel ini menjadi jelas (Wikipedia, 2020).

\section{METODE}

Objek kajian dalam studi ini terfokus pada pemakaian media verbal bahasa yang berimplikasi terhadap kebuntuhan pemahaman terhadap wacana Islam Nusantara. Datanya berupa bahasa Indonesia yang digunakan dalam polemik pro dan kontra terhadap isu Islam Nusantara, yang terpublikasi di media sosial, youtube. Pengumpulan data digunakan metode simak dengan teknik sadap, SBLC, unduh, dan catat. Adapun metode analisis data yang digunakan adalah constant comparative Analysis, dengan teknik pilah unsur penentu, teknik hubung banding menyamakan, teknik hubung banding membedakan, dan teknik hubung banding menyamakan hal pokok (cq.PODESVA dan DEVyAnI, 2013; NuRHADI, 2014).

\section{HASIL DAN PEMBAHASAN}

Isu Identitas Simbolik Berdasarkan data yang diperoleh, kehadiran wacana Islam Nusantara mengakibatkan terjadinya polemik antara dua kubu, yakni kubu yang pro Islam Nusantara (selanjutnya digunakan istilah PIN) dan yang kontra Islam Nusantara (selanjutnya digunakan istilah KIN). PIN adalah kubu yang mendukung gagasan Islam Nusantara, sedangkan KIN mewakili kubu yang menolak (kontra) gagasan Islam Nusantara. Dalam forum perdebatan antara PIN dan KIN yang dipublikasikan dalam media sosial, indikasinya terdapat pada partisipan debat yang secara tegas menunjukkan dua kubu yang saling bertolak sikap. Hal ini terbukti dari silang pendapat para partisipan dalam acara 'Pro dan Kontra' yang diselenggarakan Jak TV, yang merupakan acara live yang diselenggarakan pada tanggal 5 Juli 2015 dan dipublikasikan lewat Youtube. Acara ini dipandu oleh seorang presenter, yang berikutnya disingkat PRES. Adapun peserta debat terdiri atas 4 orang, yang masing kubu PIN dan KIN diwakili 2 orang. Keempat nama peserta tidak disebutkan lengkap, tapi dipergunakan nama singkatan, yakni kubu 
PIN diwakili SEY dan AS dan kubu KIN diwakili MN dan MM. Keempat peserta debat adalah tokoh intelek dari kedua kubu PIN dan KIN.

Kebenaran isu PIN dan KIN seperti disebutkan di atas dapat disimak pada

data (1) yang berupa tuturan pengantar yang dikemukakan PRES sebagai berikut.

(1) PRES : Ya pemirsa isu Islam Nusantara memang kerap menjadi pembahasan akhir-akhir ini. Itu saja menimbulkan pro dan kontra.

Data (1) yang dikemas dalam bentuk tuturan literal itu merujuk pada makna

referensial 'pemberitaan bahwa terdapat dua kubu, PIN dan KIN yang sedang berpolemik tentang gagasan Islam Nusantara.'Tuturan tersebut juga mengisyaratkan bahwa 'isu Islam Nusantara menjadi pokok bahasan yang masih urgen sampai sekarang.'Perlu diketahui bahwa sejak pertama gagasan Islam Nusantara disosialisasikan dalam Muktamar Nahdatul Ulama ke-33, reaksi sebagian masyarakat Muslim adalah menolak gagasan tersebut sehingga muncul dua kubu PIN dan KIN. Perhatikan data (2) berikut.

(2) Pres : Ini kubu Islam Nusantara. Ini Islam mana, nih?

$\mathrm{MN}$ : Islam jalan tengah.

Data (2) berisi pernyataan pancingan PRES untuk memperoleh reaksi dari kubu KIN yang diwakili MN. Tuturan PRES yang memberi batas kubu PIN dengan pernyataan "Ini kubu Islam Nusantara," kemudian dia memancing reaksi kubu KIN dengan pernyataan "Ini kubu mana?" Tuturan PRES ini dikemas dengan menggunakan tuturang non-literal dan tidak langsung, yang kemudian direaksi MN dengan pernyataan "Islam jalan tengah." Jawaban MN ini dilihat dari segi makna referensial merujuk pada posisi dia di kubu
Islam jalan tengah, yang berarti tidak masuk dalam kubu PIN maupun KIN atau kubu di antara PIN dan KIN. Jawaban MN ini sebenarnya merupakan jawaban "kilah" yang ingin menunjukkan bahwa dia di kubu netral. Namun, bila didasarkan pada konteks yang menempatkan posisi lokasional MN dalam acara Pro dan Kontra Islam Nusantara di seberang dua orang yang mewakili kubu PIN, maka tidak ada alasan baginya menolak anggapan bahwa dia sebenarnya ada di kubu KIN. Pernyataan MN "Islam jalan tengah" merupakan tuturan non-literal yang memiliki makna sosial 'Islam Nusantara.' Makna psikologis tuturan tersebut jelas adalah 'sikap penolakan terhadap Islam Nusantara.'

Hal yang menarik berdasarkan data yang diperoleh adalah strategi pancingdari PRES untuk mengarahkan peserta debat ke ranah isu identitas simbolik seperti yang terekspresi dalam data (3).

(3)PRES: Kok sekarang pakai peci? $\mathrm{MN}$ : Kita kan sering pakai peci di sini. Bahkan jadi pengamat politik pakai peci. SEY : Islam Nusantara itu pakai peci. Tuturan "Kok sekarang pakai peci" dalam data (3) merupakan pertanyaan pancingan untuk mengarahkan kubu KIN ke isu "peci" yang secara simbolik identik dengan Nahdatul Ulama. Hal ini ditegaskan oleh SEY yang mewakili kubu PIN bahwa peci identik dengan Islam Nusantara, khususnya Nahdatul Ulama.

Respons MN yang mewakili kubu PIN justru berkilah bahwa dia sering menggunakan peci, meskipun tidak dalam kapasitas acara keagamaan. Artinya, tuturan yang disampaikan $\mathrm{MN}$ memiliki makna psikologis bahwa peci tidak identik dengan simbol kelompok keislaman tertentu. Dengan demikian, makna sosial tuturan tersebut adalah peci bisa digunakan oleh siapa pun dan tidak bersifat eksklusif. Ketika PRES 
melemparkan isu "sorban" sebagai simbol identitas, MN memberikan respons seperti pada data berikut.

(4)PRES: Seharusnya pakai surban, Pak. $\mathrm{MN}$ : Itu Islam Arab, itu.

Penolakan MN terhadap pernyataan PRES yang mengidentikkan kubu KIN dengan simbol "sorban" justru ditolak dengan strategi pengalihan isu bahwa simbol sorban identik dengan Islam Arab.

Data (1) s.d. (5) jelas membuktikan adanya dua kubu yang memiliki perspektif berbeda dalam memandang ajaran Islam, meskipun sama-sama berpijak pada hukum Alquran dan Hadis. Selain itu, fakta adanya pemilahmilahan masyarakat muslim berdasarkan identitas simbolik pada masing-masing kubu yang saling berseberangan. Kubu KIN menolak anggapan peci identik dengan kubu PIN dan sekaligus mengklem dirinya diposisi netral yang identik dengan "Islam jalan tengah." Ada nuansa menolak konsep identitas simbol, seperti halnya menolak istilah Islam Nusantara. Kebenaran dugaan ini akan terbukti berdasarkan data yang akan disajikan berikutnya. Namun, ketika dia mengidentikkan sorban adalah Islam Arab, pernyataannya menunjukkan ketidakkonsistenan dalam bersikap. Penolakan dari Segi Istilah Penolakan kubu KIN terhadapwacana Islam Nusantara karena dianggap memberikan efek negatif terhadap umat Islam di luar Islam Nusantara. Fenomena tersebut terlihat pada data (5) berikut.

(5)MN : Ya, saya ingin, eee ... membicarakan terlebih dahulu terhadap istilahnya. Kalau ada istilah Islam Nusantara, ini kan jadi terasa seperti yang dikatakan Mbak Syarif, Mbak Rahma tadi bahwa ada Islam Indonesia, Islam Nusantara itu ya. Islam Indonesia, ada Islam Malaysia, nanti ada Islam Afrika dan sebagainya. Nah, ini kan jadinya kontradiksi interminis. Jadi sudah kontradiktif.
Tuturan MN dalam (5) merupakan premis bahwa istilah Islam Nusantara akan berefek negatif terjadinya kontradiksi interminis seiring kemungkinan munculnya istilah-istilha setara seperti istilah Islam yang merujuk pada negara-negara lain. Efek yang dikhawatirkan MN bisa dilihat pada data berikut.

(6)MN : Jadi seolah-olah, misalnya yang dibicarakan Islam Indonesia itu adalah Islam yang toleran, Islam yang ramah, misalnya. Seolah-olah Islam itu di tempat lain tidak ramah, tidak toleran. Padahal sesungguhnya ajaran Islam itu kan ya ramah.

Argumentasi MN dibangun dengan mendasarkan pada kemungkinankemungkinan psikologis bahwa umat Islam di luar teritorial Islam Nusantara akan tersinggung dan tidak bisa menerima karena merasa dianggap tidak ramah dan tidak toleran yang berbalikan dengan Islam Nusantara yang menempatkan label sebagai Islam yang toleran dan ramah. Argumentasi MN tampak tidak menyasar dari substansi konsep Islam Nusantara yang justru memiliki latar belakang pemunculan akibat keprihatinan adanya kepincangan perlakukan hukum tidak hanya di Indonesia, justru di negara-negara lain seperti tersirat pada data (7) berikut.

(7) AS : . . penyamaan warga negara di depan hukum tanpa membedakan agama, etnis, dan lain sebagainya. Ini juga berbeda dengan di negara lain. Saya tidak sedang mengatakan baik buruk. Tergantung. Makanya itu tergantung. Kalau di Arab tidak sama. Di Malaysia tidak samaantara Muslim, Cina, dan India. Kemudian di, apa, di Darussalam, di Brunei, dalam konstitusinya mengatakan bahwa penduduk asli adalah orang Melayu. Non-Melayu dianggap bukan penduduk asli. Kita bisa mengatakan, itu ekpresi Islam Brunei, itu ekspresi Islam Malaysia. 
Data (7) menjelaskan bahwa wacana Islam Nusantara bukan sekadar ekses psikologis dari negara di luar Indonesia seperti yang dituduhkan kubu KIN, melainkan sudah masuk ke substansi humaniti tentang penyamaan warga negara di depan hukum, sebagai bentuk keprihatinan terhadap fakta di negara-negara lain yang masih terjadi diskriminasi sosial. Konsep yang diusung Islam Nusantara inilah yang menjadi model yang tidak hanya di tawarkan di negara sendiri, melainkan ke negara-negara lain, khususnya yang dilanda konflik. Jadi jelas bahwa keberatan KIN terhadap istilah Islam Nusantara bukan hal yang prinsip karena dasar argumen yang mereka bersifat spekulatif, yang bertolak belakang dengan konsep Islam Nusantara yang sudah mesuk ke hal yang mendasar dan hakiki pada diri manusia, yakni hak asasi manusia sebagai akibat keprihatinan terhadap fakta terhadap pelanggaran HAM di beberapa negara lain, khususnya negara yang sedang bertikai. Persaingan Klasik Dua Kubu Bukan hanya istilah yang dipermasalahkan, kubu KIN melalui MM telah melakukan upaya pendegradasian nilai gagasan Islam Nusantara yang dianggap tidak luar biasa.

(8) MM : Jadi begini. Saya melihat begini. Tema yang diangkat... Ini dengan segala hormatnya, . . tema yang diangkat oleh NU mungkin ini juga menjadi khas dari NU. Dan, juga berbeda dengan Muhammadiyah. Kalau Muhammadiyah itu biasanya berbicara tentang kemajuan, Islam berkemajuan, peradaban, dan sebagainya. NU biasanya berputar pada Islam Indonesia, NKRI, harga final. Itu kan, seperti itulah ciri khasnya NU, style-nya seperti itu. Nah, padahal kalau menurut saya, ini orang luar pun bisa, bisa juga menafsir begini.

Pendegradasian tersebut terlihat pada isuisu yang diangkat oleh Nahdatul Ulama yang dianggap bukan gagasan yang luar biasa.
Unsur merendahkan terlihat pada cuplikan data (8): Nah, padahal kalau menurut saya, ini orang luar pun bisa, bisa juga menafsir begini. Artinya, gagasan yang diusung oleh Nahdatul Ulama bisa dengan mudah digagas oleh siapa pun. Apabila kita cermati, makna sosial yang terekspresi pada data (8) justru menunjukkan indikasi adanya persaingan antardua kubu, yakni Muhammadiyah dan Nahdatul Ulama. Mengunggulkan kubu sendiri dengan merendah kubu lain terekspresi pada data (8).

Pendegradasian nilai gagasan Islam Nusantara semakin jelas terlihat pada data berikut.

(9) MM: Justru yang belum selesai dengan budaya lokal, Nusantara itu bisa jadi itu malah NU. Bisa jadi ditafsir seperti itu. Karena selalu mengangkat tema-tema seperti ini. Ya, kan? Dan ini menurut saya, ee, . . justru dikedepankan bagaimana Indonesia ke depan, begitu kan. dan tidak kemudian menengok ke belakang. Ini tidak bisa dilepaskan, ya. Masyarakat akan menilai bahwa NU itu seperti itu.

Data ini jelas mendiskreditkan amalan Nahdatul Ulama sebagai kontra produktif karena dianggap mengangkat tema-tema yang tidak urgen dan tidak relevan dengan kemajuan umat. Apabila kita cermati, pendiskreditan tersebut mengindikasikan adanya penggiringan opini terhadap pembenaran asumsi kubu KIN dengan mengatasnamakan masyarakat sebagai penilai kebenarannya. Hal yang terjadi adalah manipulasi pembenaran dengan mengatasnamakan masyarakat yang tidak jelas identitasnya. Apakah masyarakat pada umumnya, atau masyarakat kubu KIN, yang tentu saja tidak termasuk masyarakat kubu PIN. 
Budaya sebagai Inti Permasalahan Dalam kaitannya dengan budaya, kubu KIN telah mengklaim bahwa Muhammadiyah memiliki kemajuan di bidang budaya. Padahal bidang budaya merupakan bidang inti yang dikonsepsikan dalam Islam Nusantara. Perhatikan data (10) berikut.

(10) MM : Justru itu ada persoalannya yang belum selesai di NU dalam kaitanya dengan budaya. Kalau katakanlah di internal Muhammadiyah, itu sudah dianggap selesai. Sudah tidak dibahas lagi. Jadi bahwa ada di Muhammadiyah kemajuan-kemajuan terkait dengan relasi budaya, luar biasa juga.

Data tersebut menegaskan bahwa di bidang budaya Muhammadiyah mengalami kemajuan yang luar biasa. Kemajuan itu dicontohkan seperti tersaji dalam data (11).

(11)MM Sekarang misalnya sekedar contoh, perguruan-perguruan Muhmmadiyah, sekolah-sekolah Muhammadiyah, marowis itu sudah biasa, hadroh itu biasa. Itu bagian dari, yang itu dalam istilahnya Mas Slamet itu Islam Nusantara. Itu, kan. Artinya yang khas. Bagi saya itu tidak perlu diperdebatkan.

Kemajuan Muhammadiyah di bidang budaya seperti disebutkan pada (11) merupakan kemajuan yang bersifat formatif, bukan bersifat substantif. Padahal Islam Nusantara yang digagas Nahdatul Ulama justru tidak sekadar mengusung budaya secara formatif, melainkan lebih menekankan pada mentalitas budaya yang sampai saat ini masih menjadi permasalahan bangsa Indonesia. Coba kita simak kembali data (7), jelas bahwa Islam Nusantara merespon adanya isu dekadensi kemanusiaan yang terjadi tidak hanya di Indonesia, justru di negara- negara lain di dunia, khususnya tentang persamaan hak. Jadi bukan masalah kemajuan budaya yang bersifat formatif seperti pengekspresian budaya berupa marowis, hadroh, dan lain sebagainya, yang sudah menjadi hal biasa di lingkungan Nahdatul Ulama.

Masalah budaya, memang, merupakan inti dari gagasan Islam Nusantara. Budaya merupakan permasalahan yang mendasar di Indonesia hingga sampai saat ini masih belum terpecahkan. Permasalahan budaya ini menyangkut masalah mental budaya yang memicu lahirnya gagasan Islam Nusantara. Perhatikan data berikut.

(12) Tapi yang khas dari salah satu Islam

Nusantara yang kita konsepkan itu adalah bahwa yang pertama adalah nasioalisme. Jadi, meskipun Indonesia bukan negara Islam, tetapi itu negara yang berbentuk final yang berdasarkan Pancasila. Ini berbeda, misalnya, dengan, tidak berarti mana yang baik, mana yang buruk, silakan. Tapi berbeda dengan Malaysia, dengan Arab Saudi, eee... apa, dengan yang lain-lain. Yang kedua adalah penyamaan warga negara di depan hukum tanpa membedakan agama, etnis, dan lain sebagainya. Ini juga berbeda dengan di negara lain. Saya tidak sedangmengatakan baik buruk. (Pemandu: Di Islam kan harus sama, ya?). Tergantung. Makanya itu tergantung. Kalau di Arab tidak sama. Di Malaysia tidak sama antara Muslim, Cina, dan India. Kemudian di, apa, di Darussalam, di Brunei, dalam konstitusinya mengatakan bahwa penduduk asli adalah orang Melayu. Non-Melayu dianggap bukan penduduk asli. Kita bisa mengatakan, itu ekpresi Islam Brunei, itu ekspresi Islam Malaysia.

Ada dua isu yang diangkat oleh Islam Nusantara adalah nasionalisme dan hak asasi manusia. Jelas, isu tersebut merupakan masalah yang cukup urgen dan mendasar 
mengingat masalah tersebut merupakan masalah mentalitas budaya. Sebenarnya pro dan kontra wacana Islam Nusantara itu pada dasarnya merupakan masalah budaya, khususnya masalah mentalitas budaya bangsa. Pro dan kontra itu merpakan implikasi dari pertikaian antara dua kubu organisasi Islam terbebesar di Indonesia, yakni Muhammadiyan dan Nahdatul Ulama. Mari kita simak pada data berikut.

(13) SEY : Bagaimana Nahdatul Ulama ketika, sekarang, kita menyatakan Islam Nusantara, bukan main caci makinya. Luar biasa. Jangankan itu, amalia Nahdatul Ulama, setiap tradisi Nahdatul Ulama yang berkaitan dengan agama, sejak puji-pujian, selawatan, maulud nabi, selalu dihakimi dengan Hadis "Kullu bid'atin dholalah, wakullu dhollalabtin finnaar."

Tuturan pada (13) jelas ada unsur pelabelan penyesatan dari kubu yang satu ke kubu yang lain. Kubu yang memberi pelabelan penyesatan adalah Muhammadiyah yang ditujukan kepada Nahdatul Ulama. Dalil yang digunakan oleh Muhammadiyah untuk menghakimi Nahdatul Ulama adalah dalil bid'ah. Adapun tuturan itu jelas bermakna sosial: 'protes terhadap tindakan agresi yang dilakukan Muhammadiah yang menganggap amalan ibadah yang dilakukan mereka sesat.' Keagresifan kubu KIN yang identik dengan Muhammadiyah terlihat dari respon mereka terhadap protes kubu PIN seperti pada data berikut.

(14) MM : Pak Slamet, jadi begini. Kalau saya mempunyai pandangan begini. Orang yang gampang membid'ahkan, kemudian orang yang nggak mau dibid'ahkan sebenarnya "padha-padha gendenge."

Kubu KIN dalam merespon protes kubu PIN dikemas dengan manipulasi solusi yang tendensius. Pernyataannya seakan berupa solusi, tapi dibaliknya terdapat unsur makna sosial yang menohok. Makna psikologisnya berisi anggapan bahwa 'amalan Nahdatul Ulama tidak baik dan bid'ah atau amalan yang sesat'. Berdasarkan kasus ini, terdapat pertikaian antara kubu Muhammadiyah dan Nahdatul Ulama, dengan kubu Muhammadiyah berposisi sebagai agresor, sedangkan kubu Nahdatul Ulama sebagai pemertahan. Posisi sebagai pemerintahan terlihat dari cara kubu PIN terlihat dari respons terhadap kritik kubu KIN dengan pernyataan yang berbentuk klarifikasi seperti data berikut.

(15)SEY: Oo, enggak. Nggak bisa. Orang yang sudah punya amalan kok dianggap gendheng.

Tuturan data (15) memiliki makna referensial yang merujuk pada "penolakan sebutan gila bagi kelompok mereka yang ter-bid'ah. Makna sosialnya adalah 'memprotes pernyataan lawan debatnya yang dugaannya tidak mendasar.' Makna psikologinya adalah 'orang yang sudah melakukan amalan yang baik tidak sesat.' Pada intinya istilah "gila" dapat disepadankan dengan kata "sesat." Dengan demikian, pernyataan SEY sebagai yang mewakili PIN atau Nahdatul Ulama bersifat klarifikasi dan sekaligus menegaskan bahwa pihak pem-bid'ah tidak memahami konsep Islam Nusantara.

\section{PEMBAHASAN}

Jadi, berdasarkan paparan di atas, kebuntuan terhadap pemahaman isu wacana Islam Nusantara menyangkut 4 hal, yakni identitas simbolik, penolakan dari segi istilah, persaingan klasik antarkubu, dan budaya sebagai inti permasalahan. Kebuntuhan terhadap pemahaman terhadap identitas simbolik disebabkan oleh pengaruh kepentingan baik individu maupun. Peci sebagai contoh, diidentikkan dengan santri Nadtul ulama, 
sedangkan kelompok lain menganggap peci simbol nasionalis. Identitas simbolik peci secara historis lebih sebagai identitas sekelompok Islam nasionalis. Dalam perjalanan sejarah, identitas simbolik peci bergeser maknanya ke peminpin nasionalis yang membawa simbol kebangsaan Indonesia yang pancasilais. Dalam konstelasi perpolitikan di Indonesia, pemakaian peci menjadi sarat dengan kepentingan. Tokoh nonMuslim pun memakai peci apabila mengikuti kegiatan kenegaraan. Bahkan hal yang menarik adalah ketika para kriminal diadili dipersidangan, mereka cenderung menggunakan peci untuk menarik simpati pelaku sidang.

Sorban justru diidentikkan dengan kelompok Islam Arab atau Islam Timur Tengah.Atau, sorban bisa diidentikkan dengan kelompok Islam ekstrem, kaku, dan kearab-araban. Pandangan ini perlu dipertanyakan kebenarannya mengingat terdapat fakta yang menunjukkan bahwa terdapat beberapa ulama Islam moderat menggunakan sorban, seperti di antaranya politikus Ali Ngabalin dan Ustad Abdullah Gymnastiar. Hal yang menarik adalah terjadi perubahan penampilan dari kedua tokoh Islam tersebut, yaitu mereka melepaskan atribut sorban dan menggantinya dengan peci. Apakah hal tersebut mengisyaratkan adanya pemerkuatan simbol sorban identik dengan Islam ekstrem, Islam intoleran, dan sebagainya. Untuk menjawab kebenaran ini, tentu perlu dilakukan penelitian lebih lanjut.

Berikut adalah kebuntuan dalam memahami istilah Islam Nusantara. Seperti diketahui bahwa sebagian kalangan Islam di Indonesia tidak setuju pemakaian istilah Islam Nusantara karena bisa memberikan ekses negatif yang secara psikologis bisa menimbulkan ketersinggungan dari kalangan muslim di luar Islam Nusantara. Artinya, Islam Nusantara yang membawa atribut sebagai Islam yang ramah dan toleran akan menimbulkan kontradiksi interminis yang bisa memberi presenden negatif bahwa Islam di luar Islam Nusantara merupakan Islam yang tidak ramah dan intoleran. Pendapat ini tentu bersifat spekulatif dan tidak mendasar karena menekankan pada "kemungkinan" yang belum terbukti kebenarannya. Padahal gagasan wacana Islam Nusantara merupakan model yang ditawarkan sebagai alternatif dalam berbangsa dan bernegara yang humaniti berdasarkan kearifan lokal yang memiliki kesejalanan dengan ajaran agama Islam. Selanjutnya, gagasan Islam Nusantara sebagai upaya mengakselerasi gerakannya untuk berkontestasi dengan kelompok-kelompok yang menginginkan wajah Timur Tengah di Indonesia (MINARSIH, 252-2019).

Penolakan Istilah Islam Nusantara yang digagas kubu PIN oleh kubu KIN pada dasarnya merupakan babakan berkelanjutan dari sejarah panjang persaingan klasik antara dua organisasi Islam terbesar di Indonesia, yakni Muhammadiyah dan Nahdatul Ulama. Problematika penolakan gagasan Islam Nusantara masuk dalam substansi amalan dari dua prespektif yang berbeda. Muhammadiyah beranggapan bahwa konsep yang terdapat dalam Islam Nusantara merupakan presentasi dari amalan ibadah umat Islam di bawah naungan Nahdatul Ulama yang dianggap bid-ab berdasarkan dalil: "Kullu bid'atin dholalah, wa kullu dhollalabtin finnaar." Artinya, "semua perbuatan ibadah di luar peraturan ajaran Islam adalah sesat." Dengan kata lain, perbuatan di luar peraturan ajaran Islam dikatakan sesat, atau oleh ulama Muhammadiyah disebut bid'ah. Soal inilah yang menimbulkan perselisihan antara kedua kubu, yakni Muhammadiyah dan Nahdatul Ulama. Dari perspektif Nahdatul Ulama, istilah kullu tidak diartikan 'semua', melainkan 'sebagian.' Berdasarkan pengertian tersebut, Nahdatul Ulama membuat tesis bahwa perbuatan di luar peraturan ajaran Islam sebagian bisa dikatakan sesat dan sebagian diperbolehkan, atau tidak bid'ah. Perbedaan perspektif terhadap 
amalan ibadah ini lah yang menjadi konflik antara kedua kubu organisasi tersebut, dan bahkan perkembangan lebih lanjut justru mengarah pada persaingan untuk menanamkan pengaruh terhadap umat Islam di Indonesia.

Demikian pula dengan masalah budaya, Muhammadiyah mengklaim bahwa masalah budaya sudah selesai dan bahkan diklaim bahwa implementasi budaya sudah maju di kalangan mereka. Pernyataan tersebut merupakan upaya pendegradasian terhadap gagasan yang terkonsep dalam Islam Nusantara, yang mengusung isu budaya. Argumentasi yang dibangun KIN sebagai represtasi dari Muhammadiyah tidaklah mendasar mengingat kemajuan budaya yang mereka kemukakan lebih bersifat formatif, belum menyentuh substansi budaya yang secara esensial demikian mendasari humaniti kemanusiaan.

Jadi, inti permasalahan pro dan kontra wacana Islam Nusantarapada dasarnya terletak pada persaingan antara kedua kubu organisasi Islam terbesar di Indonesia, yakni Muhammadiyah dan Nahdatul Ulama dengan mengangkat isu khilafiyah. Persaingan itu didasarkan pada perspektif yang berbeda antar kedua organisasi terhadap amalan ibadah. Ekses persaingan telah mengarah pada tindakan yang tidak sehat, yang menjurus pada perang opini yang dikemas dengan media verbal yang berisi penilaian, penghakiman, hujatan, bahkan cacian, dan perkataan kasar lain yang tidak sesuai dengan nilai-nilai "akhlakul karimah" yang diajarkan dalam Alquran dan Hadis.

\section{KESIMPULAN}

Berdasarkan bukti-bukti empirik seperti dipaparkan di atas, terdapat kebuntuan dalam memahami konsep Islam Nusantara yang berakibat munculnya dua kelompok pro dan kontra yang melibatkan dua organisasi terbesar di Indonesia, yaitu Muhammadiyah dan
Nahdatul Ulama. Kebuntuan pemahaman itu meliputi kebuntuan isu identitas, istilah Islam Nusantara, persaingan klasik dua kubu, dan budaya sebagai inti permasalahan. Faktor esensial terjadinya kebuntuan disebabkan oleh adanya kepentingan, baik kepentingan individu maupun golongan yang bermuara pada sejarah perselisihan klasik yang panjang dalam memandang amalan ibadah dari perspektif yang berbeda.

\section{DAFTAR PUSTAKA}

\section{Ali, Athian.}

12 Agustus 2018. "Kesesatan Islam Nusantara." Dalam Masjid Istiqamah Bandung (Online). https://www.youtube.com/watch?v=Yi2RedRn $9 \mathrm{ww}$.

\section{BasAlamah, SyafiQ Riza.}

9 September 2015. "Tanya Jawab: Islam Nusantara": Dalam Yufid.TV (Online). https://www.youtube.com/watch?v= ZWk86n1OjC4 . Diunduh 16 Juni 2020.

BublitZ, WOLFRAM dkk [Ed.]. 2011. Schneider Handbooks of Pragmatics. Boston: De Gruyter Mouton.

Capone, Alessandro dkk [Ed]. 2013. Perspectives on Linguistic Pragmatics. New York: Springer.

\section{Cummings, LOUISE.}

2007. Pragmatik, Sebuah Prespektif Multidisipliner. Yogyakarta: Pustaka Pelajar.

\section{Cummings, LOUISE.}

2014. Pragmatic Disorders. New York: Springer.

\section{GUSRIZAL, BuYA.}

27 Juli 2028. "Amanah Kamu Tunaikan.” Dalam Sumbar Time (Online). Https://sumbartime.com/amanah-kamitunaikan-by-buya-gusrizal- gazahar/ . Diunduh 21 Juni 2020. 
HANGFM BATAM.

18 Februari 2016. "Kajian Islam - Islam Nusantara dalam Timbangan."

https://www.youtube.com/watch?v=4EVnT Xlo9Mc . Diunduh 16 Juni 2020.

Jaktv Official Channel.

15 Juli 2015. "Pro Kontra Wacana Islam Nusantara." https://www.youtube.com/watch?v=i562Qw PO1Ug . Diunduh 10 Juni 2020.

KompasTV.

31 Maret 2018. "Gus Dur dan Islam Nusantara: Singkap.

https://www.youtube.com/watch?v $=$ HCoj0

Gi_4j4 . Diunduh 14 Juni 2020.

\section{LOCASTO, VIRGINIA.}

2012. Pragmatics for Language Educators:

Sociolinguistic Perspective. New York:

Roudledge.

MEY, JACOB L.

2009. Concise Encyclopedia of Pragmatics. Oxford: Elsevier.

NURHADI, TAUFIK.

2014. Tuturan Pembangun Citra Diri Positif: Kajian Berdasarkan Pendekatan Teori Makna Tripartit. Dalam Setali 2014. Bandung: MLI Cabang Bandung.

Pennisi, A. dan A. Falzone.

2020. The Extended Theory of Cognitive Creativity: Interdisciplinary Approaches to Performativity. Switzerland: Springer International Publishing.

\section{Podesva, Robert j dan Devyani}

SHARMA [Ed.].

2013. Research Methods in Linguistics. Cambridge: Cambridge University Press.
Republika.Co.Id.

25 Juli 2018. "MUI Sumbar Kukub Tolak Istilah Islam Nusantara."

Https://republika.co.id/berita/pchar5384/muisumbar-kukuh-tolak-istilah-islam-nusantara . Diunduh 15 Juni 2020.

SAHANA, MinARSIH.

25 Fabruari 2019. "Pribumisasi Islam di Indonesia dan Islam Nusantara." Dalam VOA Indonesia (Online). Https://www.voaindonesia. $\mathrm{com} / \mathrm{a} /$ pribumisasi-islam-di-indonesia-danislam-nusantara/4802554.html. Diunduh 21 Juni 2020.

Wikipedia. "Islam Nusantara." 2020. https://id.wikipedia.org/wiki/Islam_ Nusantara . Diunduh 5 Mei 2020. 